\title{
Implementation of E-Learning Method in Earthquake Learning
}

\author{
Rahmati Ismail* \\ Study Program of Geography Education \\ Universitas Samudra \\ Aceh, Indonesia \\ *aty.aceh@unsam.ac.id
}

\author{
Myrza Akbari \\ Study Program of Sport Education \\ Universitas Samudra \\ Aceh, Indonesia
}

\begin{abstract}
The research objective was to explore the application of e learning-based learning in earthquake learning, to determine the effect of e-learning learning on the quality of student learning and to see the effectiveness of learning using the e-learning method. This type of research is quantitative with this type of research survey which is expected to explain the reality of using E-Learning in learning. This study aims to measure the application of e-learning to school students. This research uses a qualitative approach to the type of case study. The setting of this research is Senior High School of Banda Aceh. The research subjects were teachers and students. Collecting data through observation, in-depth interviews, and documentation study. The results of this study indicate that: 1 . E-learning has a positive and significant effect on the quality of student learning. 3. The influence is in the strong category, the more intensively elearning is used, the quality of student learning will also increase, 3. The use of e-learning web will improve learning outcomes indirectly, 3. The purpose of using e-learning in the learning system is to expand access to education for the wider community, as well as in order to improve the quality of learning.
\end{abstract}

Keywords-E-leraning, earthquake, disaster

\section{INTRODUCTION}

When science and technology develop rapidly, the learning process is no longer monopolized by the presence of teachers in the classroom. Students can study anywhere and anytime [1]. This is also supported by the statement [2] which states that the development of information technology can improve performance and enable activities to be carried out quickly, precisely, and accurately, resulting in high productivity. elearning as an electronic medium can have a changing impact on the learning process. the purpose of using e-learning in the learning system is to expand access to education to the wider community.

The interaction between students and teachers does not always have to be face to face, students can start learning on their own using electronic media with developing technology as an intermediary so that the teaching and learning atmosphere becomes more attractive, visual, and interactive.
E-Learning is a network, which can be updated, stored / retrieved, distributed, and shared instructions and information sent to users directly via a computer using standard internet technology [3]. Harton in Zyainuri and Eko [4] defines elearning as the use of information technology and computers to create learning experiences. Based on this theory, e-learning is an electronic based learning media using technology in the form of computers. It is hoped that the development of an elearning learning model in schools can improve students' preparedness in anticipating earthquakes.

There are many ways to create an innovation in making a learning atmosphere fun, interesting but still meets the criteria of good learning. From the results of research conducted by Nuryanti [5] regarding the teaching and learning process through the e-learning learning model in general, it can improve the abilities of students with the results showing that the implementation of the e-learning learning model can make the learning atmosphere more interesting and the interaction between teachers and teachers. students become effective, so that students are increasingly interested in participating in learning.

One of the fields that have had a significant impact on the development of this technology is the field of education, where basically education is a process of communication and information from educators to students that contains educational information, which has elements of education as a source of information, media as a means of presenting ideas, ideas and educational materials as well as the students themselves [6], some parts of this element get a touch of information technology media, so that the idea of e-learning was born.

E-learning is a combination of information, communication, education, and training which is a core element for achieving general educational goals. The basic device used is a set of computers that have internet access, without having internet access, it is difficult for students and teachers to practice e-learning [7]. E-learning is the development of internet technology in education. 
E-Learning is a relatively new information technology in Indonesia. E-learning consists of two parts, namely "e" which stands for electronica and learning which means "learning". Elearning means learning using the help of electronic devices. In its implementation, e-learning uses audio, video or computer services or a combination of the three. In other words, elearning is learning whose implementation is supported by technological assistance such as telephone, audio, video tape, satellite, or computer transmissions [8].

E-learning is also a form of conventional learning that is expressed in digital format through internet technology. Therefore e-learning can be used in distance education systems as well as conventional education systems [9]. E-learning is now increasingly recognized as a way to solve educational problems, both in developed countries and developing countries. Many people use different terms with e-learning, but in principle e-learning is learning that uses electronic services as a means of assistance [10]. The learning process using the elearning model or with the help of electronic equipment is expected to improve student learning outcomes.

From these theories it can be concluded that e-learning is a form of distance education that uses electronic media as a medium for delivering material and communication between teachers and students.

The benefits of the e-learning model in the learning process according to Soekartawi's opinion [10] are:

- The availability of facilities where teachers and students can communicate easily through the internet on a regular basis or at any time, such communication activities are carried out without being limited by distance, place, and time.

- Teachers and students can use instructional materials or learning instructions that are structured and occur via the internet, so that both can assess each other to what extent the teaching materials are studied.

- Students can study or review teaching materials at anytime and anywhere if necessary, remembering the teaching materials are stored on the computer.

- If students need additional information related to the material they are learning, they can access the internet more cheaply.

- Both teachers and students can conduct discussions via the internet that can be followed by a large number of participants, thereby increasing knowledge and broader insights.

- Changing the role of students from being passive to being active.

From this description, the benefits of using the e-learning model can make it easier for students to communicate with their teachers, and teachers and students can use stored materials and can use discussions via the internet anytime and anywhere, thus students will start to be active in learning.
The learning process through electronic media, especially the internet, is currently considered to be an educational solution for students who cannot physically attend school but have a high interest in acquiring knowledge [11].

According to Sutomo [12] the strategy of using e-learning to support the implementation of the learning process is expected to:

- Improve students' ability to absorb subject matter.

- Increase the active participation of students and improve students' independent learning abilities.

- Improve the quality of education and training materials.

- Increasing the ability to display information with information technology devices, which is difficult to do with ordinary devices.

- Expanding the reach of the teaching and learning process using computer networks, not limited to space and time.

Applications must provide sufficient information to accommodate students' exploration of information. Learn something by setting a goal to be achieved (goal-directed learning). The student is positioned as someone who has to achieve the goals / objectives and the application provides the facilities needed to do so. Students then develop independent strategies to achieve these goals.

\section{METHODS}

This type of research is quantitative with this type of research survey which is expected to explain the reality of using E-Learning in learning. respondents in this study consisted of 299 students. Data collection techniques in this study used online questionnaires using Microsoft Form from Office 365 aimed at students. The questionnaire contains several questions whose contents are expected to describe the percentage of the use of the ELearning application in earthquake learning

\section{RESULTS}

From the data collected by researchers at Senior high school 5 Banda Aceh, it was found that students 'responses to the implementation of e learning in their schools were found, as for the students' responses can be seen in the following description.

There were 28 students' responses about whether the elearning model had been implemented before or $93.3 \%$ of students answered "never" because of the lack of facilities at the school, and only 2 students or $6.7 \%$ answered "yes". Furthermore, $100 \%$ of students answered that they easily got information related to earthquakes using the e-learning learning model and $100 \%$ of students said they liked geography learning which was done by applying the e-learning model on the grounds that it was more effective and they became more 
active, and 93, 3\% of students felt motivated to study earthquake material using the e-learning model because learning became more interesting, faster or easier to understand because the explanation was clearer, but $6.7 \%$ answered that they were not motivated to study earthquake material using the e-model. learning on the grounds that learning e-learning is a little difficult.

The e-learning model can also make it easier for students to communicate with the teacher, this can be seen from the percentage results, namely $63.3 \%$ answered "yes", and $36.7 \%$ answered no on the grounds that the teacher was busier explaining in front. Furthermore, 90\% of students answered "yes" that the way the teacher delivered material with the elearning model helped it easier to understand geography learning on the grounds that students felt more able to concentrate, and the teacher explained the material very clearly so that it made students understand more quickly in learning geography, and $10 \%$ of students answered "no" without the reasons stated by the students.

\section{DISCUSSION}

Many things can be done through e-learning in the learning process, including 2 (two) things, namely:

\section{A. Looking for the Subject Matter of Learning}

The learning process in the form of looking for learning material, consists of the following steps:

- Teachers convey basic competencies as well as several indicators to students along with an internet site that can be visited regarding these basic competencies and indicators.

- Students download learning materials that are in accordance with the basic competencies and indicators presented by the teacher on the sites indicated by the teacher, in this case students are given the opportunity to search on sites other than those shown by the teacher.

- After editing, if necessary, students send the download results to the web site or email the teacher.

- The teacher edits the main material sent by the students, edits it, namely by reducing the material sent by students if the discussion is too broad, or adding if the material sent by students is too short, so that it does not meet the indicators desired by the teacher.

- After editing, the teacher sends to the student's email address if the subject matter of the lesson has been adjusted based on the desired indicators.

\section{B. Implementation of Daily Tests and Block Repetitions}

Through e-learning, a teacher does not need to spend too much energy, thought and money to always carry out daily tests or block tests with multiple choice questions. The things that are needed before the implementation of block tests or daily tests with e-learning include:

- The teacher prepares a collection of questions, it would be better if there are enough questions but still within the corridor of the indicators desired by the teacher, so that the questions can be randomized so that each participant is not exactly the same. the score that will be obtained for each participant.

- This program should be equipped with minimum learning completeness criteria, as well as explanations for correct or wrong answers for remedial purposes for those who have not reached the criteria of learning completeness.

- Each student has a special number, for example a student registration number, as a student identity other than the name when data entry.

All Personal Computer (PC) units are connected to a Local Area Network (LAN) with a server for teachers, where question banks and other supporting programs are stored.

\section{CONCLUSIONS}

As for the conclusions of the discussion are as follows Conclusion

- E-learning has a positive and significant effect on the quality of student learning, the influence is in the strong category.

- The more intensively e-learning is used, the quality of student learning will also increase.

- The use of e-learning web will improve learning outcomes indirectly.

\section{REFERENCES}

[1] E.B. Podgorsak,. External photon beams: Physical aspects. Radiation Oncology Physics: A handbook for teachers and students'. Vienna: IAEA, 2005.

[2] B.L. Nuryanti, "Model Pembelajaran E-Learning Melalui Homepage Sebagai Media Pembelajaran Sehingga Diharapkan Dapat Meningkatkan Minat Dan Kreativitas Siswa," Jurnal ABMAS (Media Komunikasi dan Informasi Pengabdian Kepada Masyarakat), vol. 9, pp. 1-7, 2009.

[3] R. Noveandini and S.W. Maria, "Utilization of Online Learning Media (E-Learning) for Career Women in Efforts to Increase Effectiveness and Flexibility in Monitoring the Learning Activities of Primary School Students," National Seminar on Information Technology Application 2010 (SNATI 2010). Yogyakarta, 2010.

[4] Z. Zyainuri and E. Marpanaji, "Penerapan e-learning moodle untuk pembelajran siswa yang melaksanakan prakerin," Jurnal Pendidikan Vokasi, vol. 2, no. (3), 2012

[5] S. Siahaan, "Why You Should Use E-learning in Learning Activities," Journal Media Pembelajaran, vol. XII, no. P23, 2008.

[6] B.S.D. Oetomo and J. Priyogutomo, "Kajian Terhadap Model e-Media dalam Pembangunan Sistem e-Education," In Makalah Seminar Nasional Informatika, 2004. 
[7] D. Kurniahayati and S. Syamsurizal, "Pengembangan Pembelajaran Berbasis Web Centric Course pada Materi Stoikiometri untuk Meningkatkan Minat Belajar Siswa di SMA Titian Teras Jambi,” EduSains: Jurnal Pendidikan Matematika dan Ilmu Pengetahuan Alam, vol. 1, no. (1), 2012.

[8] T. Tafiardi, "Improving the Quality of Education through E-Learning," Journal Pendidikan Penabur, no.0 4/Th.IV/ Juli 2005.

[9] A. Anwas, "E-learning Innovation Model in Improving Education Quality," Jurnal Teknodik, no. 12/VII /October/2003.
[10] S. Soekartawi, "Prinsip dasar e-learning teori dan aplikasinya di Indonesia," Jurnal Teknodik, no.12/VII/TEKNODIK, pp. 5-27, 2003

[11] W. Wina, Perencanaan dan Desain Sistem Pembelajaran. Jakarta: Media Grafika, 2010

[12] M. Sutomo, "E-learning sebagai Alternatif Model Pembelajaran dalam Upaya Meningkatkan Mutu di Perguruan Tinggi,” Jurnal Falasifa, vol. 3, no. (1), pp. 149-159, 2012. 